\title{
The Impact of Natural Water Quality on Baking Products in Albania
}

\author{
Valbona Sinani $^{1}$, Majlinda Sana ${ }^{2}$, Elton Seferi ${ }^{3}$, Abdyl Sinani ${ }^{3}$ \\ ${ }^{1}$ Faculty of Economics and Agribusiness, Agriculture University of Tirana, Tirana, Albania \\ ${ }^{2}$ Aleksandër Moisiu University, Durres, Albania \\ ${ }^{3}$ Faculty of Food Biotechnology, Agriculture University of Tirana, Tirana, Albania \\ Email: eltonseferi@gmail.com
}

Received 15 October 2014; revised 12 November 2014; accepted 7 December 2014

Copyright (C) 2014 by authors and Scientific Research Publishing Inc.

This work is licensed under the Creative Commons Attribution International License (CC BY). http://creativecommons.org/licenses/by/4.0/

cc) (i) Open Access

\begin{abstract}
Water, a simple chemical ingredient, is so important during the process of cooking and baking product as flour. Its functions in baking processes are numerous, some of which are not entirely clear, while others are evaluated by characteristics of the mature product. Regardless of its origin, the water shall be drinkable to be used in processes of baking. In this study, four types of water of the country which are Spring water, Lajthiza, Tepelena and Trebeshina are evaluated. Three factors that must be considered in relation to water quality, such as taste, content of chemicals and mineral content are evaluated. Identification of an unusual taste or bad smell in water can change the taste of the final product. Chlorine is considered a chemical ingredient that has significant effects on the quality of the dough, especially in the fermentation activity. Yeast, being a natural microorganisem, is sensitive to chlorine. Also a high level of chlorine affects the function of flour and enzymes especially. Mineral content of the water determines the hardness and softness of the water, where strong water contains a large amount of minerals, while soft water contains a very limited amount of minerals. Dough characteristics may be affected by the minerals content in water: minerals used by the yeast nutrient, so a change in their concentration in the water affects at the fermentation process. As a result, a change in fermentation will affect at the dough characteristics, making it stronger or weaker. In a wider sense of functionality of baking ingredient products, it is very important to control the baking process and final production of a consistent quality. Often, when quality is not within the required standards and used not adequately, water can be a determining factor for obtaining the desired dough and final product characteristics.
\end{abstract}

\section{Keywords}

Water Quality, Variety of Wheat, Dough, Bakery Products 


\section{Introduction}

Water is an important ingredient in the dough for baking products. In most of the time, the tap water is used to make the dough. However, technically speaking, water quality may have some effects on dough characteristics, product characteristics, and the proper function of certain parts of the equipment. Three factors that must be considered in relation to water quality are evaluated. They are: taste, content of chemicals and mineral content.

Identification of an unusual taste or odor in the water can change the taste of the final product. Chlorine is considered as a chemical ingredient that has significant effects on the quality of pulp, especially in fermentation activity. Yeast, being a natural microorganism, is sensitive to chlorine. Also a high level of chlorine affects the function of flour and in particular the enzymes. Mineral content of the water determines the hardness and softness of the water, where strong water contains a large amount of minerals, while soft water contains a very limited amount of minerals [1]-[7].

Dough characteristics may be affected by the content of minerals in the water: minerals are used by the yeast nutrient, so a change in their concentration affects the fermentation process. Consequently, a change in fermentation will affect the characteristics of the dough, making it stronger or weaker.

In a wider sense of functionality baking ingredient products, it is very important to control the baking process and finished products with a consistent quality. Often, when the quality is not within the required standards and used improperly, water may be a determining factor for obtaining the desired dough and final product characteristics [8]-[14].

The purpose of this study is to recognize the determined qualitative properties of some water resources and our country's flour physico-chemical parameters during the baking to the final product.

\section{Materials and Methods}

The water for drinking should be considered to have a constant temperature ranging from $6^{\circ} \mathrm{C}$ to $12^{\circ} \mathrm{C}$, there should be no abnormal taste or odor. Also there should be no color and should be fine. Clarity of water is an indication of lack of insoluble substances, however this feature is very relative because they are very few waters that have not hover substances (Schedule 1).

\section{Results and Analysis}

In this study, Spring water, Lajthiza, Tepelena and Trebeshina were obtained in the study of four types of groundwater in the country. Chemical analysis carried out have enabled the identification of contamination with fecal origin, those organic and inorganic type, such information is obtained by performing analysis for determining organic substances, ammonia, chlorine (organic pollution in action), nitrites and nitrates and inorganic elements that may be present due to the infiltration of emissions that come from the surrounding industrial areas.

It is important that whether from the perspective of drinking, as well as the suitability of use in any industry, insoluble salts and their composition are defined.

For this purpose, the power of water which is classified into is defined:

Total power: Evaluation of the concentration of $\mathrm{Ca}$ and $\mathrm{Mg}$ salts in water.

Temporary Power: The concentration of $\mathrm{Ca}$ and $\mathrm{Mg}$ salts found as bicarbonate.

Permanent power: $\mathrm{Ca}$ and $\mathrm{Mg}$ salts that remain undigested in the water after it has been boiled.

Units of measurement of water power are:

"French"-this grade hydrometric corresponds to $1 \mathrm{~g}$ calcium carbonate in 100 liters of water;

"German"- this grade corresponds to $1 \mathrm{gr}$ of calcium oxide in 100 liters of water;

"English"- this grade corresponds to 1 gr carbonate in $700 \mathrm{ml}$ water.

Water with power $5^{\circ}$ is classified as sweet, $5^{\circ}-20^{\circ}$ common strength and with power over $30^{\circ}$ very strong. Normal boundaries of strength are $30^{\circ} \mathrm{F}$ for total power and $12^{\circ} \mathrm{F}$ to it permanently. Since the dough should have a $\mathrm{pH}$ value around $5-6$, when it is used for the preparation of alkaline water, dough have a pH higher than 8, with fewer gas production and lower acidity and a higher duration maturity due to the lower activity of the yeast, diastasis and lactic bacteria. 
Schedule 1. Characteristics required for drinking water.

\begin{tabular}{|c|c|c|c|c|c|}
\hline \multicolumn{2}{|c|}{$\begin{array}{l}\text { The limit of acceptable substances or } \\
\text { drinking water features }\end{array}$} & \multicolumn{2}{|c|}{$\begin{array}{l}\text { Maximum acceptable limit of toxic } \\
\text { substances in drinking water }\end{array}$} & \multicolumn{2}{|c|}{$\begin{array}{l}\text { Acceptable limit of chemical } \\
\text { substances in drinking water }\end{array}$} \\
\hline Parameter & $\begin{array}{l}\text { Concentration or } \\
\text { value limits }\end{array}$ & Parameter & $\begin{array}{l}\text { Concentration or } \\
\text { value limits }\end{array}$ & Parameter & $\begin{array}{l}\text { Concentration or } \\
\text { value limits }\end{array}$ \\
\hline Smell & Pronounced & Arsenic (As) & $0.05 \mathrm{mg} / \mathrm{l}$ & Iron $(\mathrm{Fe})$ & $0.2 \mathrm{mg} / \mathrm{l}$ \\
\hline Color & 100 unit & Barium (Ba) & $1.00 \mathrm{mg} / \mathrm{l}$ & Magnesium (Mg) & $50 \mathrm{mg} / \mathrm{l}$ \\
\hline Blur & $250 \mathrm{ppm}$ in $\mathrm{SO}_{2}$ & Cadmium (Cd) & $0.01 \mathrm{mg} / \mathrm{l}$ & Manganese (Mn) & $0.5 \mathrm{mg} / \mathrm{l}$ \\
\hline Ammonia $\left(\mathrm{NH}_{4}\right)$ & $0.5 \mathrm{mg} / \mathrm{l}$ & Cyanide (CN) & $0.05 \mathrm{mg} / \mathrm{l}$ & Copper (Cu) & $0.1 \mathrm{mg} / \mathrm{l}$ \\
\hline Copper (Cu) & $1 \mathrm{mg} / \mathrm{l}$ & Chromium $\left(\mathrm{Cr}_{6}\right)$ & $0.05 \mathrm{mg} / \mathrm{l}$ & Zinc (Zn) & 5 mg/l \\
\hline Zinc (Zn) & $5 \mathrm{mg} / \mathrm{l}$ & Bullet (Pb) & $0.05 \mathrm{mg} / \mathrm{l}$ & Chloride $\left(\mathrm{Cl}^{-}\right)$ & $250 \mathrm{mg} / \mathrm{l}$ \\
\hline Bullet (Pb) & $0.05 \mathrm{mg} / \mathrm{l}$ & Selenium (Se) & $0.01 \mathrm{mg} / \mathrm{l}$ & Fluoride $\left(F^{-}\right)$ & $1 \mathrm{mg} / \mathrm{l}$ \\
\hline Cadmium (Cd) & $0.005 \mathrm{mg} / \mathrm{l}$ & \multirow{6}{*}{\multicolumn{2}{|c|}{$\begin{array}{l}\text { Should also check the presence of these } \\
\text { substances: mercury, vanady, molybdenum } \\
\text { and silver. } \\
\text { Conversely need to make sure that the } \\
\text { concentration of organic substances } \\
\text { extracted by chloroform (ECC), as } \\
\text { polycyclic aromatic hydrocarbons it } \\
\text { should not exceed } 0.2 \mathrm{mg} / \mathrm{l} \text { and not } \\
\text { have the presence of pesticides. }\end{array}$}} & Nitrates $\left(\mathrm{NO}_{3}\right)$ & $50 \mathrm{mg} / \mathrm{l}$ \\
\hline Arsenic (As) & $0.05 \mathrm{mg} / \mathrm{l}$ & & & Sulfate $\left(\mathrm{SO}_{4}\right)$ & $250 \mathrm{mg} / \mathrm{l}$ \\
\hline Chrome $\left(\mathrm{Cr}_{6}\right)$ & $0.01 \mathrm{mg} / \mathrm{l}$ & & & Detergents (ABS) & $0.3 \mathrm{mg} / \mathrm{l}$ \\
\hline Selenium (Se) & $0.05 \mathrm{mg} / \mathrm{l}$ & & & $\begin{array}{l}\text { Phenolic compounds } \\
\text { (phenol) }\end{array}$ & $0.0001 \mathrm{mg} / \mathrm{l}$ \\
\hline Cyanide (CN $\left.{ }^{-}\right)$ & $1 \mathrm{mg} / \mathrm{l}$ & & & & \\
\hline Fluoride $\left(\mathrm{F}^{-}\right)$ & $0.5 \mathrm{~g} / \mathrm{l}$ & & & & \\
\hline Detergents (ABS) & $0.3 \mathrm{mg} / \mathrm{l}$ & & & & \\
\hline $\mathrm{pH}$ & $6-8.5$ & & & & \\
\hline BOD & 10 & & & & \\
\hline COD & 30 & & & & \\
\hline Nitrates $\left(\mathrm{NO}_{3}\right)$ & $50 \mathrm{mg} / \mathrm{l}$ & & & & \\
\hline Nitrates $\left(\mathrm{NO}_{2}\right)$ & $0.1 \mathrm{mg} / \mathrm{l}$ & & & & \\
\hline
\end{tabular}

\subsection{Bacteriological Requirements}

Microbiological analysis of water intended to detect drinking value by determining the number and type of microorganisms. At present, the greatest risk to drinking water display is potential contamination from sewage wastewater that can filter through the soil into underground water, which enables the development of pathogenic bacteria in drinking water.

The indicator of fecal contamination is Escherichia coli, but since such a determination is not very simple, preferably generally determined fecal coliform.

Microbiological analysis, research except for some other types of bacteria, should determine the number of possible bacteria in $100 \mathrm{ml}$ of water; so the amount of contamination and the type of microorganisms reach the defined measures and types of treatment we should take to make drinking water (Schedule 2).

\subsection{Impact of Water on Quality of Baked Products}

Mineral substances dissolved in the water though presented only as traces of inorganic substances in baked products, also affect the processing of pasta as well as consistency of finished products. The sweet water affects the creation of a sticky dough, a phenomenon that can be avoided by adding dough improvers or a larger amount of salt, while monokalcik phosphate is typically used as "correction" of water for the production of bread or food for the yeast. The addition of $\mathrm{Mg}$ and Ca salts causes an increase in the severity of dough. This phenome- 
Schedule 2. Classification bacteriological water used as drinking water.

\begin{tabular}{lc}
\hline \multicolumn{1}{c}{ Classification } & Bacteria (ml water) \\
\hline 1) Water should be sterilized & $0-50$ \\
2) Water should be coagulated, filtered and sterilized & $50-5000$ \\
3) Water requires a special treatment & $5000-50,000$ \\
4) The waste water, with no possibility of treatment and should seek other sources & $>50,000$ \\
\hline
\end{tabular}

non finds explanation in the reaction that occurs between gluten proteins with $\mathrm{Ca}$ and $\mathrm{Mg}$ ions, forming cross links.

Positive effects on fermentation and bread volume were observed when added 50 - 500 ppm magnesium chloride, 100 - 1000 ppm calcium carbonate and 50-300 ppm calcium sulphate.

Another indicator of the analytical water, which retains its importance by bread making technological side, is $\mathrm{pH}$ since for an optimal development of its value dough should be $5-6$. The use of alkaline water $(\mathrm{pH}>7.5)$ enables the production of a dough with $\mathrm{pH}$ higher than 6 , causing a poor manufacturing gas and a longer baking time due to reduced activity of the yeast, and diastazës lactic bacteria. Alkaline water has a negative effect on gluten to form and its plasticity: it is therefore necessary to use water with a slight acidity.

The use of chlorinated water is noticed that provokes a reduction of the fermentation time and improves the quality of bread, particularly if used weak flour. Influence of chlorine can change if it is found or as combined chlorine residual in the water sterilization treatment.

\section{Results and Analysis}

To study the impact of natural water quality of our country in bakery products are studied physico-chemical parameters of wheat cultivars (Table 1), Farinograph physical parameters (Table 2), as well as extensograph physical parameters. The results obtained from the present study are presented as follows:

Referring to Table 1, the two types of grains are used in production of flour for bread production in the mixture $40 \%$ Russian cultivar and 60\% Agimi cultivar, while best quality baker has Spring and Lajthiza water.

Referring to Table 2, grain analysis show that it of Russian type has better properties of rehology compared with Agimi type, where the factors that determine this feature are: water absorption 58.5\%, dough development time $2.4 \%$, stability 10.2 and softness 53 min EP.

Production of bread, and harmonization of two cultivars of wheat cultivar respectively $60 \%$ Russian cultivar and $40 \%$ Agimi cultivar (Table 3):

Chemical parameters of production are:

$\begin{array}{ll}\text { Humidity } & 14 \% \\ \text { Protein } & 14.6 \% \\ \text { Ash } & 0.60 \%\end{array}$

Farinograph characteristics of production are:

$\begin{array}{ll}\text { Water absorption } & 59.5 \% \\ \text { Development time } & 1.6 \mathrm{~min} \\ \text { Stability } & 2.8 \mathrm{~min} \\ \text { Smoothing degree } & 149 \mathrm{PE}\end{array}$

To analyze the impact of physico-chemical factors of water in bread product under consideration waters are as follows: Spring, Lajthiza, Tepelena and Trebeshina (Figure 1).

Using our waters analyzed for the production of bread was taken following conclusions (Table 4):

Table 4 shows that $\mathrm{pH}$ of the Spring water is 5.97, the factor which affect on $\mathrm{pH}$ of dough that turns out to be 5.6. All waters of analyzed are hardness and content $\mathrm{Mg}^{2+}, \mathrm{Ca}^{2+}$ and $\mathrm{NO}_{3}^{-}$in normal value.

Physical- and chemical characteristics, where the bread is baked in different types of water, is shown in the table as follows (Table 5):

Data from the analysis of the breads, reflected in Figure 2, show that bread production by Spring and Lajthiza water have greater volume compared to other types of water; as a consequence, these breads have higher porosity and measure. 
Table 1. Phsico-chemical parameters of wheat cultivars.

\begin{tabular}{cccccc}
\hline Cultivars & Humidity (\%) & Proteins (\%) & Hectolitre weight & Sediment & Hardness \\
\hline Agimi (Lushnje) & 11.9 & 13.4 & 78 & 45 & 44 \\
Russian & 12.1 & 14.3 & 80 & 49 & 55 \\
\hline
\end{tabular}

Table 2. Phsical parameters of farinograph.

\begin{tabular}{cccccc}
\hline Cultivars & $\begin{array}{c}\text { Water absorption } \\
(\%)\end{array}$ & $\begin{array}{c}\text { Development } \\
\text { time (min) }\end{array}$ & Stability (min) & Softness (PE) & Maximum (PE) \\
\hline Agimi (Lushnje) & 62.5 & 4.1 & 6.3 & 87 & 511 \\
Russian & 58.5 & 2.4 & 10.2 & 53 & 513 \\
\hline
\end{tabular}

Table 3. Extensograph physical parameters of Russian and Agimi cultivars.

\begin{tabular}{|c|c|c|c|c|c|c|}
\hline Cultivars & Russian & Agimi & Russian & Agimi & Russian & Agimi \\
\hline Time & 14.47 & 12.36 & 15.29 & 13.18 & 16.11 & 14.00 \\
\hline Arrival time of dough & 45 & 45 & 90 & 90 & 135 & 135 \\
\hline Resistance in traction & 274 & 208 & 303 & 209 & 294 & 231 \\
\hline Elasticity & 203 & 176 & 183 & 159 & 182 & 161 \\
\hline Maximum & 425 & 296 & 478 & 294 & 495 & 315 \\
\hline Energy & 114 & 69 & 112 & 60 & 111 & 65 \\
\hline Index number & 1.35 & 1.18 & 1.65 & 1.31 & 1.61 & 1.43 \\
\hline
\end{tabular}

Table 4. Characteristics of waters under study.

\begin{tabular}{ccccc}
\hline Characteristics & Spring Water & Lajthiza Water & Tepelena Water & Trebeshina Water \\
\hline Temperature at source & $8.5^{\circ} \mathrm{C}$ & $60^{\circ} \mathrm{C}$ & $9.3^{\circ} \mathrm{C}$ & $11.4^{\circ} \mathrm{C}$ \\
The dry residue in $180^{\circ} \mathrm{C}$ & $38.54 \mathrm{mg} / \mathrm{l}$ & $89 \mathrm{mg} / \mathrm{l}$ & $130.0 \mathrm{mg} / \mathrm{l}$ & $35.12 \mathrm{mg} / \mathrm{l}$ \\
Free carbon dioxide & $1.70 \mathrm{mg} / \mathrm{l}$ & $2.8 \mathrm{mg} / \mathrm{l}$ & $2.10 \mathrm{mg} / \mathrm{l}$ & $2.10 \mathrm{mg} / \mathrm{l}$ \\
Hardness to ${ }^{\circ}$ Germany & $5.59^{\circ} \mathrm{G}$ & $2.2^{\circ} \mathrm{G}$ & $3.9^{\circ} \mathrm{G}$ & $6.2^{\circ} \mathrm{G}$ \\
pH in source & 5.97 & 8.1 & 8.34 & 10.1 \\
${\text { Magnesium } \mathrm{Mg}^{2+}}_{\text {Calcium } \mathrm{Ca}^{2+}}$ & $24.3 \mathrm{mg} / \mathrm{l}$ & $36.0 \mathrm{mg} / \mathrm{l}$ & $0.48 \mathrm{mg} / \mathrm{l}$ & $7.4 \mathrm{mg} / \mathrm{l}$ \\
Sodium $\mathrm{Na}^{+}$ & $1.7 \mathrm{mg} / \mathrm{l}$ & $1.19 \mathrm{mg} / \mathrm{l}$ & $52.6 \mathrm{mg} / \mathrm{l}$ & $7.32 \mathrm{mg} / \mathrm{l}$ \\
Chloride $\mathrm{Cl}^{-}$ & $1.4 \mathrm{mg} / \mathrm{l}$ & $1.12 \mathrm{mg} / \mathrm{l}$ & $1.60 \mathrm{mg} / \mathrm{l}$ & $25 \mathrm{mg} / \mathrm{l}$ \\
Nitrate $\mathrm{No}^{3-}$ & $5.1 \mathrm{mg} / \mathrm{l}$ & $7.16 \mathrm{mg} / \mathrm{l}$ & $26 \mathrm{mg} / \mathrm{l}$ & $<40 \mathrm{mg} / \mathrm{l}$ \\
Bicarbonate $\mathrm{HCO}_{3}$ & $0.16 \mathrm{mg} / \mathrm{l}$ & $1.3 \mathrm{mg} / \mathrm{l}$ & $1.60 \mathrm{mg} / \mathrm{l}$ & $1.3 \mathrm{mg} / \mathrm{l}$ \\
Potassium $\mathrm{K}^{+}$ & $124.7 \mathrm{mg} / \mathrm{l}$ & $55 \mathrm{mg} / \mathrm{l}$ & $147.3 \mathrm{mg} / \mathrm{l}$ & $183 \mathrm{mg} / \mathrm{l}$ \\
Fluor $\mathrm{F}^{-}$ & $<1 \mathrm{mg} / \mathrm{l}$ & $0.63 \mathrm{mg} / \mathrm{l}$ & $0.34 \mathrm{mg} / \mathrm{l}$ & $0.58 \mathrm{mg} / \mathrm{l}$ \\
\hline
\end{tabular}

Table 5. Physical and chemical characteristics of bread samples.

\begin{tabular}{cccccc}
\hline Water used & Bread volume $(\mathrm{cm})$ & Quantity $\left(\mathrm{kg} / \mathrm{cm}^{3}\right)$ & Crumb moisture (\%) & Crumb porosity (\%) & Rate test (1 - 10) \\
\hline Sample 1 & 13 & 0.405 & 41.0 & 74 & 76.5 \\
Sample 2 & 12.5 & 0.371 & 42 & 73 & 7.2 \\
Sample 3 & 11 & 0.378 & 42.8 & 7.0 & 73.6 \\
Sample 4 & 10 & 0.379 & 40 & 8.7 \\
\hline
\end{tabular}




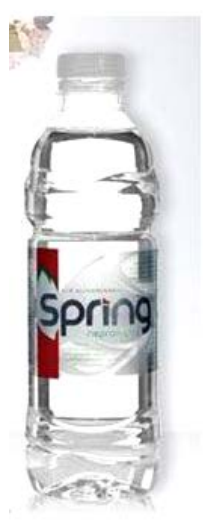

Spring water

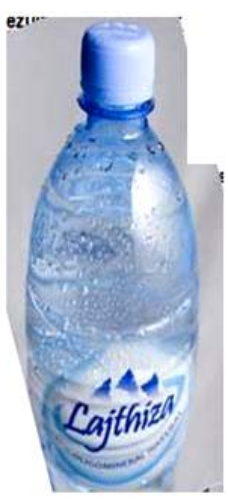

Lajthiza water

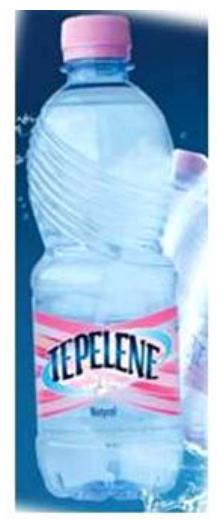

Tepelena water

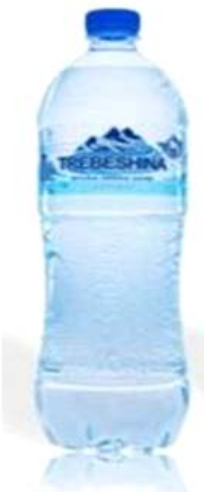

Trebeshina water

Figure 1. Illustrative photo of water used.

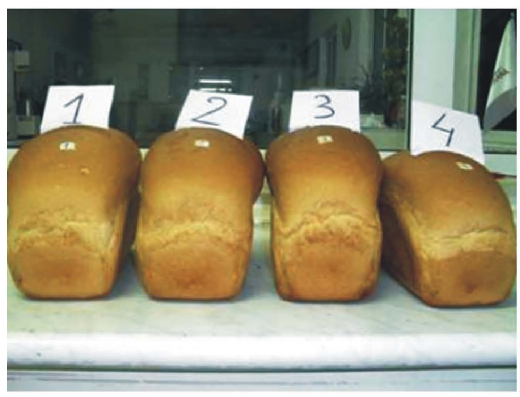

Bread production by different types of water: 1 -Spring water

2-Lajthiza water;

3-Tepelena water;

4-Trebeshina water.
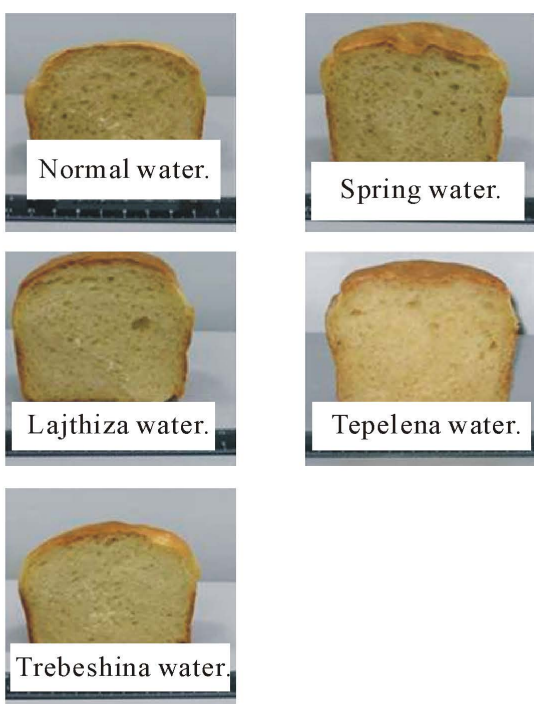

Figure 2. Photos of bread samples are shown in the photos as follows.

\section{Conclusions}

Our study has shown that water with $\mathrm{pH} 7$ - 8.2 (Lajthiza water) is successfully used for producing good quality bakery products, where reactivation affects optimal yeast in dough.

By the study, it resulted that water resources Trebeshina, with $\mathrm{pH} 9.0-9.8$ dhe ORP $80.6 \mathrm{mV}$, enable the production of the dough to cause poor gas production and a longer baking time due to reduced activity of the yeast, diastasis and lactic bacteria. Alkaline water has a negative effect on gluten to shape and its plasticity, therefore it is necessary to use water with a slight acidity.

The migration of water through the stages of dough depends directly on ingredients containing low molecular weight. Thus, the role of sugars and oligosaccharides, salts, lipid and surfactants in any aqueous colloidal system relates to the position in the lipotropic series and varies due to the type of water. Assessing the content of salts, Sprig and Lajthiza water has salts content in the optimal amount for a good quality of bread.

The addition of calcium salts, where the content has lower Lajthiza water, has caused an increase in the severity of dough and poor quality of bread with Trebeshina water content. This phenomenon is reflected by the reaction that occurs between gluten proteins with calcium ions, forming cross links.

\section{References}

[1] Allan, J.A. (1998) Virtual Water: A Strategic Resource. Global solutions to regional deficits. Groundwater, 36, 545- 
546. http://dx.doi.org/10.1111/j.1745-6584.1998.tb02825.x

[2] Barthélemy, F., Renault, D. and Wallender, W. (1993) Water for a Sustainable Human Nutrition: Inputs and Resources Analysis for Arid Areas. UC Davis Internal Report, 70 p.

[3] Colin, L. (2002) Method to Estimate Virtual Water Trade around the World and Analysis of First Results. Report of Internship, WWC-INAPG, 63 p.

[4] Cosgrove, W.J. and Rijsberman, F. (2000) World Water Vision, Making Water Everybody’s Business. World Water Council, Earthscan, 108 p.

[5] FAO (1992) CROPWAT a Computer Program for Irrigation Planning and Management. FAO Irrigation and Drainage Technical Paper No. 46.

[6] Hoekstra, A.Y. and Hung, P.Q. (2002) Virtual Water Trade: A Quantification of Virtual Water Flows between Nations in Relation to International Crop Trade. Value of Water Research Report Series No.11, IHE, Delft.

[7] Oki, T., Sato, M., Kawamura, A., Miyake, M., Kanae, S. and Musiake, K. (2002) Virtual Water Trade to Japan and in the World. Proceedings Expert Meeting on Virtual Water, Delft, December 2002..

[8] Renault, D. and Wallender, W.W. (2000) Nutritional Water Productivity and Diets: From "Crop per Drop” towards: “Nutrition per Drop". Agricultural Water Management, 45, 275-296. http://dx.doi.org/10.1016/S0378-3774(99)00107-9

[9] Renault, D. (2002) La valeur de l'eau virtuelle dans la gestion de l'alimentation humaine. Actes des 27emes journées de la Société Hydrotechnique de France, Eau et Economie, 24-26 Septembre 2002, 8 p.

[10] Renault, D. (2003) Value of Virtual Water for Food: Principles and Features. Proceedings Expert Meeting on Virtual Water, Delft, December 2002.

[11] Rosegrant, M. and Ringler, C. (1999) Impact on Food Security and Rural Development of Reallocating Water from Agriculture. IFPRI, Washington DC.

[12] Turton, A.R. (2000) Precipitation, People, Pipelines and Power: Towards a "Virtual Water" Based Political Ecology Discourse. MEWREW Occasional Paper, Water Issues Study Group, School of Oriental and African Studies (SOAS) University of London, London.

[13] Wichelns, D. (2001) The Role of "Virtual Water" in Efforts to Achieve Food Security and Other National Goals, with an Example from Egypt. Agricultural Water Management, 49, 131-151. http://dx.doi.org/10.1016/S0378-3774(00)00134-7

[14] WWC-CME (1998) L'eau au XXIème siècle. Document présenté par le Conseil Mondial de l'Eau à la Conférence de Paris Mars 1998. 
Scientific Research Publishing (SCIRP) is one of the largest Open Access journal publishers. It is currently publishing more than 200 open access, online, peer-reviewed journals covering a wide range of academic disciplines. SCIRP serves the worldwide academic communities and contributes to the progress and application of science with its publication.

Other selected journals from SCIRP are listed as below. Submit your manuscript to us via either submit@scirp.org or Online Submission Portal.
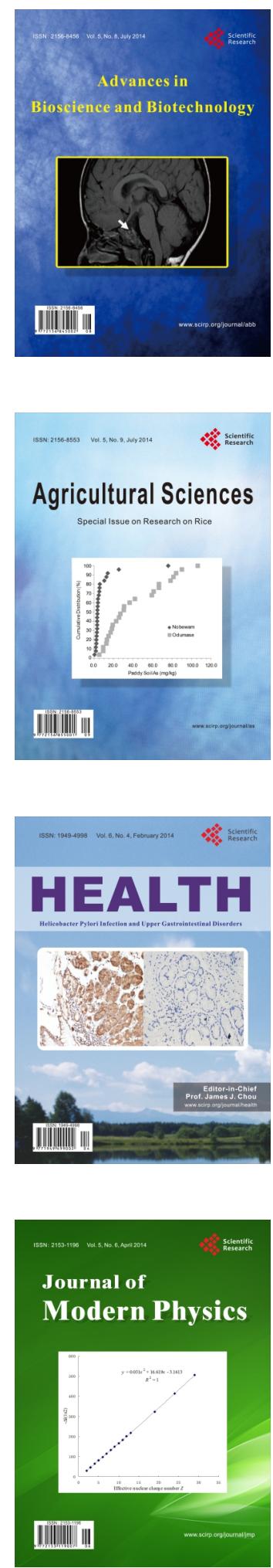
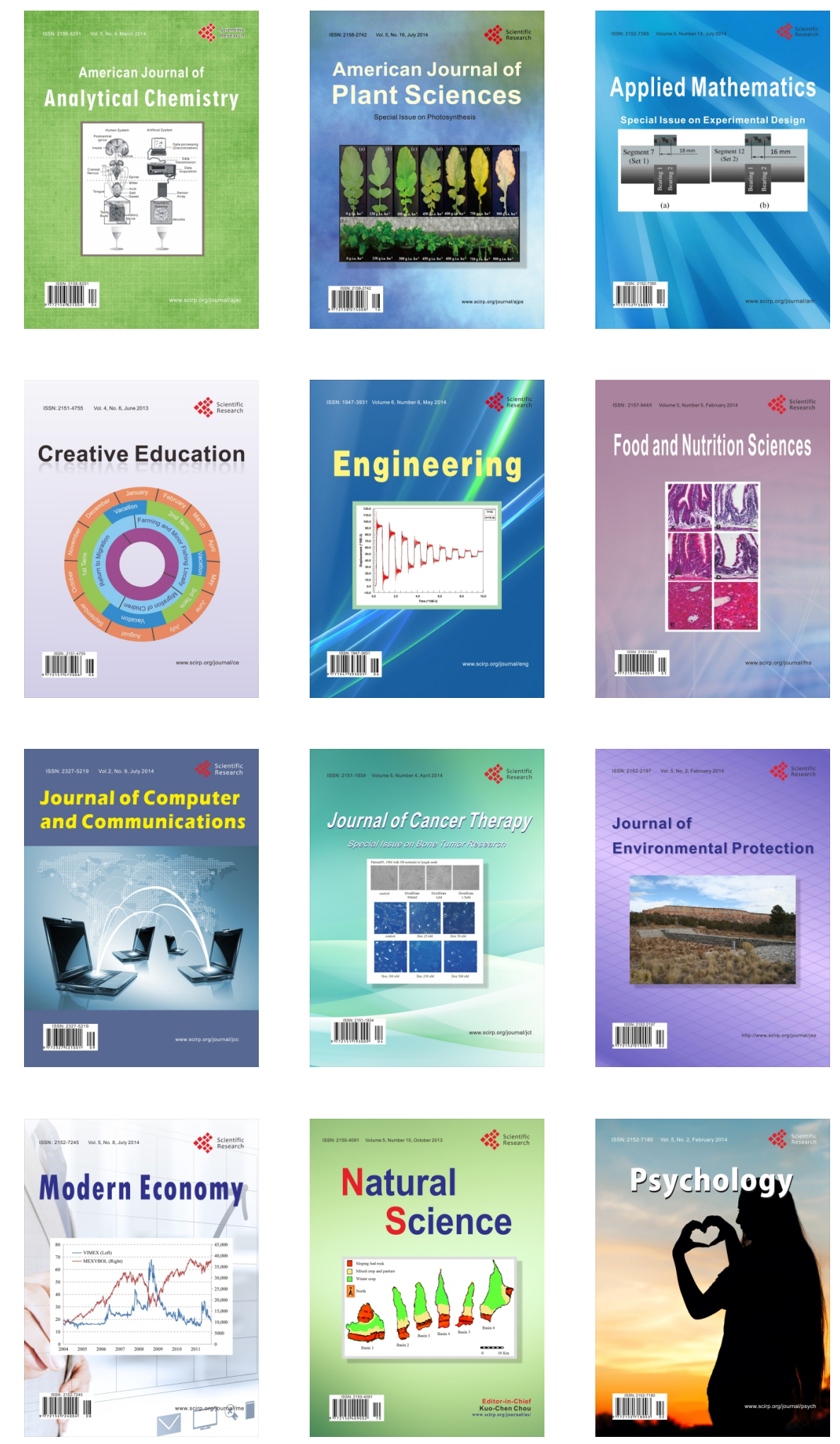